\title{
Effects of parasitoids on the severity of African rice gall midge Orseolia oryzivora H. \& G. (Diptera: Cecidomyiidea) in Koda millet, Paspalum scrobiculatum $L$ infested rice genotypes at Edozhigi in Central agro-ecological zone of Nigeria
}

\author{
A.B., Umaru*, M.C. Dike ${ }^{\star \star}$, I. Onu* and M.N. Ukwungwu* \\ ${ }^{*}$ National Cereals Research Institute, Badeggi, P.M.B. 8, Bida, Niger State, Nigeria. \\ ${ }^{*}$ Department of Crop Protection, Faculty of Agriculture IAR/ABU, Samaru - Zaria. \\ ${ }^{*}$ Corresponding authors e-mail: abumaru2003@yahoo.co.uk; Tel.: +2348069780510
}

\begin{abstract}
Experiments were conducted at Edozhigi in the Southern Guinea Savanna zone of Nigeria between $2004-2007$ on the use of $P$. scrobiculatum to enhance the biological control mechanism of Africa gall midge (AfRGM) by two naturally occurring parasitoids in six rice varieties. Both $P$. scrobiculatum as a lowland rice weed and rice as a crop have the same parasitoids range. The six varieties were FARO 51, FARO 52, FARO 37, TOS 14519, BW $348-1$ and a local variety all having varying levels of tolerance to AfRGM. These varieties as treatments were laid out in a randomized complete block design with three replicates and each was surrounded with one - metre band of $P$. scrobiculatum except the local variety as control. All the varieties were scored for gall midge infestation at 42 DAT and 63 DAT (days after transplanting) and all the galls were dissected to assess the presence of parasitoids. Results indicated that the presence of galls of $P$. scrobiculatum had moderating influence on the incidence of gall midge signifying that $P$. scrobiculatum galls were able to attract parasitoids to lower the AfRGM infestation. A fact of particular importance is that FARO 37 which is a known highly susceptible rice variety consistently maintained low levels of AfRGM.
\end{abstract}

Keywords: Parasitoids, Rice, Gall midge, Paspalum, Genotypes, Infestation

\section{INTRODUCTION}

The African rice gall midge (AfRGM), is an important pest of rice in low land systems in Africa. It has been reported in several countries like Burkina Faso (Bonzi, 1980) Dakouo et al.,1988), Nigeria (Ukwungwu et al.,1989; Ukwungwu and Joshi 1992), Umeh et al., 1991; Harris et al., 1999, Nwilene et al., 2006), Sierra Leone (Taylor et al., 1995) and also exist in other sub - Saharan African countries (Alam et al., 1985).

The damage is due to the larva penetrating into the rice stem at vegetative growth stages which makes the stem to grow into tubular form called "Silver shoots" or Onion leaves' which does not bear panicles that produce grains (Umeh and Joshi, 1993); William et al., 1999;
Bouchard et al, 1992). The spread and severity of African rice gall midge attacks in rice fields are becoming more and more frequent since the outbreak in 1986 (Ukwungwu et al., 1989) in which over 50,000 hectares of rice fields were affected in South east of Nigeria. Yield losses of 20 to $80 \%$ due to AfRGM have been recorded from endemic areas on farmer's fields and also on research fields (Dakouo et al., 1988, Nacro, et al., 1996, Williams et al., 1999; Nwilene, et al, 2006). The resource poor farmers cannot afford the economic yield losses that make low lands rice cultivation unsustainable (Dakouo et al., 1988). 
There is urgent need to prevent these serious loses and ensure sustainable rice production.

Since the beginning of the several outbreaks in West Africa, concerted research efforts have led to significant achievements in identifying sources of resistance and two main natural enemies of rice. Though there is no variety with stable resistance to AfRGM identified yet, some varieties are known to exhibit high level of tolerance to the pest like FARO 51, (Cisadane) FARO 52, BW 348 - 1 and TOS 14519 (Ukwungwu et al., 1997; Gana et al., 2000; Ukwungwu, 1986 and Ukwungwu and Alam 1991). Two natural enemies that attack AfRGM are ployembryonic endoparasitoid Platygaster displosisae Risbec (Hymenoptera; Platygasteridae) and solitary extoparasitoid (Aprostocetus Procerae Risbec. (Hymenoptera; Eulophidae (Williams et al., 1999. Incidentally these parasitoids have also been identified on the gall midge of a common weed of low land rice, which is Koda millet (Paspalum scrobiculatum) called Paspalum gall midge (Orseolia bonzii Harris. There is need to study his overlap of these parasitoids of the gall midge of rice and the gall midge of $P$. scrobiculatum to explore the possibilities of enhancing the biological control of the gall midge of rice since $P$. scrobiculatum is easily available in low lands and can be manipulated around rice stands.

The objective of this study was to enhance biological control of the AfRGM in these tolerant varieties by introducing $P$. scrobiculatum into rice for possible attraction of the parasitoids to reduce the severity of AfRGM on rice.

\section{MATERIALS AND METHODS}

\section{Experimental location}

Four field experiments were conducted at the low land rice research fields of the National Cereals Research Institute at Edozhigi $\left(9^{\circ} 45^{\mid} \mathrm{N}, 6^{\circ} 07^{\mid} \mathrm{E}\right)$ in the Southern Guinea Savana zone of Nigeria between 2004 and 2007 to reduce infestation of six tolerant rice varieties by AfRGM using Koda Millet, $P$. scrobiculatum to attract parasitoids of AfRGM.

\section{Experimental Design and Layout}

The varieties were FARO 51 (Cisadane), FARO 52 (WITA 4), FARO 37 (ITA 306), TOS 14519, BW 348-1 and a local variety. These varieties were laid out in a randomized complete block design with three replicates in gross experimental plot which measured $35 \mathrm{~m} \times 17 \mathrm{~m}$. Smaller plots which measured $5 \mathrm{~m} \times 5 \mathrm{~m}$ and separated by $1 \mathrm{~m}$ alley way were measured out. One metre band of $P$. scrobiculatum was transplanted surrounding each variety before transplanting rice except local variety as control.

\section{Agronomic Practices}

Planting was carried out at a spacing of $20 \mathrm{~cm} \times 20 \mathrm{~cm}$ using three-week old seedlings. Fertilizer application was done basally with a dose of $40 \mathrm{~kg} \mathrm{NPK} / \mathrm{ha}$ before transplanting and later top - dressed after three weeks with a dosage of $40 \mathrm{~kg} \mathrm{NPK} / \mathrm{ha}$. Hand weeding was carried out at three and six weeks after transplanting.

\section{Data Collection and Analysis}

Data collected included percentage of tillers infested by gall midge recorded from randomly selected 20 hills of each genotype at 42 DAT and 63 DAT, i.e.

$\%$ tiller infestation $=\frac{\text { No.of tillers with galls }}{\text { total number of tiller }}$

These percentages were related to the Standard Evaluation System (SES) for rice (IRRI, 1996) as shown below. All the galls were dissected and the

$\begin{array}{lll}0 & = & \text { No damage, Highly Resistant } \\ (\mathrm{HR}) & & \text { Resistant (R) } \\ \mathrm{I}< & = & \text { Moderately Resistant (MR) } \\ 1-5 & = & \text { Moderately Susceptible (MS) } \\ 6-10 & \text { Susceptible (S) } \\ 11-25 & = & \text { Highly Susceptible (HS) }\end{array}$

Numbers of parasitoids found were recorded. Agronomic data collected were days to $5 \%$ flowering, plant height at harvest, number of panicles per meter square and grain yield in $\mathrm{kg} / \mathrm{ha}$. All data were subjected to analysis of variance, using SAS (1991) and mean separation was done using Student - Newman - Keuls (SNK) procedure.

\section{RESULTS}

The results showed that there were significant differences $(P<0.05)$ among the rice genotypes in their reactions to gall midge infestation at 42 DAT (Table 1). The local variety, with no $P$. scrobiculatum infestation consistently gave highest percentage gall midge infestation differing significantly $(\mathrm{P}<0.05)$. It also rated susceptible(S) according to Standard Evaluation System for rice (SES) as against its normal status of being moderately resistant (MR) or highly resistant (HR). The lowest percentage gall midge infestation were observed among TOS 14519 and BW 348-1 throughout and rated either moderately susceptible (MS) or susceptible (S) as against their status of being highly resistant $(\mathrm{HR})$ with one instance of being moderately resistant (MR) (Table 1). FARO 37 did not exhibit its potential of being highly susceptible (HS) giving percentage that was lower than those of FARO 51 and FARO 52 with ratings as either susceptible (S) or 
Table 1. Reaction of selected rice varieties to percentage gall midge infestation at 42 DAT under $P$. scrobiculatum infestation at Edozhigi, Nigeria

\begin{tabular}{lcccc}
\hline & \multicolumn{4}{c}{ Percentage galls per variety } \\
Treatments & $\mathbf{2 0 0 4}$ & $\mathbf{2 0 0 5}$ & $\mathbf{2 0 0 6}$ & $\mathbf{2 0 0 7}$ \\
\hline FARO 51 (Cisadane) & $14.5 \mathrm{a}(\mathrm{S})$ & $16.8 \mathrm{a}(\mathrm{S})$ & $16.5 \mathrm{a}(\mathrm{S})$ & $7.6 \mathrm{~b}(\mathrm{MS})$ \\
FARO 52 (WITA 4) & $16.0 \mathrm{a}(\mathrm{S})$ & $17.1 \mathrm{a}(\mathrm{S})$ & $16.2 \mathrm{a}(\mathrm{S})$ & $13.6 \mathrm{a}(\mathrm{S})$ \\
FARO 37 (ITA 306 & $12.3 \mathrm{a}(\mathrm{S})$ & $9.3 \mathrm{~b}(\mathrm{MS})$ & $11.3 \mathrm{ab}(\mathrm{S})$ & $7.0 \mathrm{~b}(\mathrm{MS})$ \\
TOS 14519 & $7.6 \mathrm{~b}(\mathrm{MS})$ & $6.6 \mathrm{~b}(\mathrm{MS})$ & $6.8 \mathrm{~b}(\mathrm{MS})$ & $1.6 \mathrm{~b}(\mathrm{MR})$ \\
BW 348-1 & $11.3 \mathrm{ab}(\mathrm{S})$ & $5.0 \mathrm{~b}(\mathrm{MS})$ & $6.3 \mathrm{~b}(\mathrm{MS})$ & $8.6 \mathrm{~b}(\mathrm{MS})$ \\
Local Variety (Control) & $18.0 \mathrm{a}(\mathrm{S})$ & $19.8 \mathrm{a}(\mathrm{S})$ & $19.0 \mathrm{a}(\mathrm{S})$ & $15.4 \mathrm{ab}(\mathrm{S})$ \\
\hline Mean & 12.6 & 11.7 & 12.2 & 8.6 \\
S.E. $( \pm)$ & 1.2 & 1.6 & 1.4 & 1.2 \\
C.V.(\%) & 16.6 & 24.5 & 21.1 & 25.4 \\
\hline
\end{tabular}

Means within the same column followed by the same letters are not significantly different $(P=0.05)$ from one another using SNK

Table 2. Reaction of selected tolerant rice varieties to percentage gall midge infestation at 63 DAT under $P$. scrobiculatum infestation at Edozhigi, Nigeria

\begin{tabular}{lcccc}
\hline & \multicolumn{4}{c}{ Percentage galls per variety } \\
Treatments & $\mathbf{2 0 0 4}$ & $\mathbf{2 0 0 5}$ & $\mathbf{2 0 0 6}$ & $\mathbf{2 0 0 7}$ \\
\hline FARO 51 (Cisadane) & $17.3 \mathrm{a}(\mathrm{S})$ & $15.6 \mathrm{a}(\mathrm{S})$ & $15.8 \mathrm{a}(\mathrm{S})$ & $8.4 \mathrm{ab}(\mathrm{MS})$ \\
FARO 52 (WITA 4) & $16.3 \mathrm{a}(\mathrm{S})$ & $9.0 \mathrm{bc}(\mathrm{MS})$ & $14.5 \mathrm{a}(\mathrm{S})$ & $9.6 \mathrm{a}(\mathrm{MS})$ \\
FARO 37 (ITA 306 & $13.1 \mathrm{ab}(\mathrm{S})$ & $6.2 \mathrm{bc}(\mathrm{MS})$ & $9.9 \mathrm{ab}(\mathrm{MS})$ & $6.2 \mathrm{bc}(\mathrm{MS})$ \\
TOS 14519 & $8.4 \mathrm{~b}(\mathrm{MS})$ & $8.1 \mathrm{bc}(\mathrm{MS})$ & $5.1 \mathrm{~b}(\mathrm{MS})$ & $5.5 \mathrm{c}(\mathrm{MS})$ \\
BW 348-1 & $3.1 \mathrm{c}(\mathrm{MR})$ & $4.2 \mathrm{c}(\mathrm{MR})$ & $12.2 \mathrm{a}(\mathrm{S})$ & $1.8 \mathrm{~d}(\mathrm{MR})$ \\
Local Variety (Control) & $19.8 \mathrm{a}(\mathrm{S})$ & $18.7 \mathrm{ab}(\mathrm{S})$ & $16.5 \mathrm{a}(\mathrm{S})$ & $10.3 \mathrm{ab}(\mathrm{MS})$ \\
\hline Mean & 11.3 & 9.1 & 12.0 & 6.6 \\
S.E. $( \pm)$ & 1.2 & 1.5 & 1.7 & 0.6 \\
C.V.(\%) & 18.5 & 29.2 & 24.0 & 16.2 \\
\hline
\end{tabular}

Means within the same column followed by the same letters are not significantly different $(P=0.05)$ from one another using SNK

moderately susceptible (MS).

Similar trends as explained in the case of gall midge infestation at 42 DAT and ratings were also observed for infestation at 63 DAT (Table 3). In both cases of infestation at 42 DAT and 63 DAT, FARO 37 rated either susceptible (S) or moderately susceptible (MS) as against its status of being highly susceptible (HS) as observed in the case of infestation of 42 DAT (Table 2).

The dissection result of all the galls indicated presence of two prominent parasitoids. These were platygaster displosisae and Aprostocetus procerae Risbec. The general trend noticed in the case of the parasitoids was that FARO 37 had the highest numbers of either $P$. Displosisae or $A$. Procerae significantly differing $(P<0.05)$ from the remaining genotypes (Table $3,4,5$ and 6 ). Secondly, the result on tables 3 to 6 indicates that there were more of the abundance of $A$.
Procerae than $P$. Diplosisae. The Local variety recorded zero parasitoids in many cases except on table 5 where zero parasitoids were recorded once. (Table 3 to 6 ).

The results of the agronomic data taken showed that the number of days to $50 \%$ flowering varied significantly with TOS 14519 consistently maintaining highest mean (Table 7). FARO 37 had the lowest number of days to $50 \%$ flowering. The plant height at harvest appeared to have similar trends with those of number of days to $50 \%$ flowering. FARO 37 was the shortest of these varieties being significantly different from the others $(P<0.05)$. The mean of panicles per metre square was not significantly different in 2004 regardless of the variety involved. However, in 2005, FARO 37 gave the highest number of panicles per metre square while TOS 14519 consistently gave the highest in 2006 which significantly differed $(P<0.05)$ from other varieties (Table 7$)$. In 2005 , only the 
104 Int. Res. J. Agric. Sci. Soil Sci.

Table 3. Effect of $P$. scrobiculatum on the parasitism of African rice gall midge by P.diplosisae in selected tolerant rice varieties at 42 DAT at Edozhigi, Nigeria

\begin{tabular}{lcccc}
\hline & \multicolumn{4}{c}{ Mean numbers of $\boldsymbol{P}$. diplosisae } \\
Treatments & $\mathbf{2 0 0 4}$ & $\mathbf{2 0 0 5}$ & $\mathbf{2 0 0 6}$ & $\mathbf{2 0 0 7}$ \\
\hline FARO 51 (Cisadane) & $0.0 \mathrm{~b}$ & $0.0 \mathrm{~b}$ & $0.0 \mathrm{~b}$ & $5.3 \mathrm{ab}$ \\
FARO 52 (WITA 4) & $0.0 \mathrm{~b}$ & $0.0 \mathrm{~b}$ & $0.0 \mathrm{~b}$ & $4.0 \mathrm{bc}$ \\
FARO 37 (ITA 306) & $7.6 \mathrm{a}$ & $7.0 \mathrm{a}$ & $6.3 \mathrm{a}$ & $7.3 \mathrm{a}$ \\
TOS 14519 & $0.0 \mathrm{~b}$ & $0.0 \mathrm{~b}$ & $0.0 \mathrm{~b}$ & $1.0 \mathrm{~cd}$ \\
BW 348-1 & $0.0 \mathrm{~b}$ & $2.6 \mathrm{~b}$ & $3.0 \mathrm{~b}$ & $2.6 \mathrm{bcd}$ \\
Local Variety (Control) & $0.0 \mathrm{~b}$ & $1.0 \mathrm{~b}$ & 0.0 & $0.3 \mathrm{~d}$ \\
S.E $( \pm)$ & 0.1 & 0.7 & 0.6 & 0.8 \\
CV. $(\%)$ & 18.4 & 70.9 & 79.8 & 41.9 \\
\hline
\end{tabular}

Means within the same column followed by the same letters are not significantly different $(P=0.05)$ from one another using SNK

Table 4. Effect of $P$. scrobiculatum on the parasitism of African rice gall midge by P.diplosisae in selected tolerant rice varieties at 63 DAT at Edozhigi, Nigeria

\begin{tabular}{lcccc}
\hline & \multicolumn{4}{c}{ Mean numbers of $\boldsymbol{P}$. diplosisae } \\
Treatments & $\mathbf{2 0 0 4}$ & $\mathbf{2 0 0 5}$ & $\mathbf{2 0 0 6}$ & $\mathbf{2 0 0 7}$ \\
\hline FARO 51 (Cisadane) & $4.3 \mathrm{~b}$ & $6.6 \mathrm{ab}$ & $4.3 \mathrm{ab}$ & $6.6 \mathrm{a}$ \\
FARO 52 (WITA 4) & $0.0 \mathrm{c}$ & $5.0 \mathrm{~b}$ & $3.6 \mathrm{ab}$ & $5.0 \mathrm{ab}$ \\
FARO 37 (ITA 306) & $7.6 \mathrm{a}$ & $8.3 \mathrm{a}$ & $7.6 \mathrm{a}$ & $7.3 \mathrm{a}$ \\
TOS 14519 & $0.0 \mathrm{c}$ & $0.0 \mathrm{c}$ & $0.0 \mathrm{~b}$ & $0.0 \mathrm{~b}$ \\
BW 348-1 & $0.0 \mathrm{c}$ & $6.6 \mathrm{ab}$ & $3.3 \mathrm{ab}$ & $3.6 \mathrm{ab}$ \\
Local Variety (Control) & $0.0 \mathrm{c}$ & $0.0 \mathrm{c}$ & $0.0 \mathrm{~b}$ & $1.0 \mathrm{~b}$ \\
S.E $( \pm)$ & 0.8 & 0.6 & 1.3 & 1.2 \\
CV. $(\%)$ & 71.2 & 23.8 & 74.2 & 54.3 \\
\hline
\end{tabular}

Means within the same column followed by the same letters are not significantly different $(P=0.05)$ from one another using SNK

Table 5. Effect of $P$. scrobiculatum on the parasitism of African rice gall midge A.procerae in selected tolerant rice varieties at 42 DAT at Edozhigi, Nigeria

\begin{tabular}{lcccc}
\hline & $\mathbf{5}$ & Mean numbers of $\boldsymbol{A}$. procerae \\
Treatments & $\mathbf{2 0 0 4}$ & $\mathbf{2 0 0 5}$ & $\mathbf{2 0 0 6}$ & $\mathbf{2 0 0 7}$ \\
\hline FARO 51 (Cisadane) & $0.0 \mathrm{~b}$ & $3.3 \mathrm{ab}$ & $0.0 \mathrm{~b}$ & $0.0 \mathrm{c}$ \\
FARO 52 (WITA 4) & $3.0 \mathrm{~b}$ & $0.0 \mathrm{~b}$ & $0.0 \mathrm{~b}$ & $0.0 \mathrm{c}$ \\
FARO 37 (ITA 306) & $6.8 \mathrm{a}$ & $5.3 \mathrm{a}$ & $5.7 \mathrm{a}$ & $6.0 \mathrm{a}$ \\
TOS 14519 & $0.0 \mathrm{~b}$ & $0.0 \mathrm{~b}$ & $0.0 \mathrm{~b}$ & $0.0 \mathrm{c}$ \\
BW 348-1 & $0.0 \mathrm{~b}$ & $4.3 \mathrm{a}$ & $2.6 \mathrm{~b}$ & $2.6 \mathrm{~b}$ \\
Local Variety (Control) & $1.3 \mathrm{~b}$ & $1.6 \mathrm{ab}$ & $1.6 \mathrm{~b}$ & $0.0 \mathrm{c}$ \\
S.E ( \pm ( ) & 0.9 & 0.8 & 1.0 & 0.5 \\
CV. $(\%)$ & 82.1 & 63.6 & 60.0 & 64.0 \\
\hline
\end{tabular}

Means within the same column followed by the same letters are not significantly different $(P=0.05)$ from one another using SNK

grain yield of FARO 37 was significantly different $(P<0.05)$ from that of other varieties. Highest grain yields were obtained in 2006 from the local variety, FARO 52 and TOS 14519 while there was no significant difference among all the varieties in 2007 (Table 7). 
Table 6. Effect of $P$. scrobiculatum on the parasitism of African rice gall midge A.procerae in selected tolerant rice varieties at 63 DAT at Edozhigi, Nigeria

\begin{tabular}{lcccc}
\hline & \multicolumn{4}{c}{ Mean numbers of $\boldsymbol{A}$. procerae } \\
Treatments & $\mathbf{2 0 0 4}$ & $\mathbf{2 0 0 5}$ & $\mathbf{2 0 0 6}$ & $\mathbf{2 0 0 7}$ \\
\hline FARO 51 (Cisadane) & $5.3 \mathrm{a}$ & $3.3 \mathrm{~b}$ & $4.6 \mathrm{ab}$ & $3.6 \mathrm{ab}$ \\
FARO 52 (WITA 4) & $4.3 \mathrm{ab}$ & $2.3 \mathrm{~b}$ & $4.3 \mathrm{ab}$ & $4.0 \mathrm{ab}$ \\
FARO 37 (ITA 306) & $7.0 \mathrm{a}$ & $7.0 \mathrm{a}$ & $6.3 \mathrm{a}$ & $6.3 \mathrm{a}$ \\
TOS 14519 & $0.0 \mathrm{~b}$ & $0.0 \mathrm{~b}$ & $0.0 \mathrm{~b}$ & $0.0 \mathrm{~b}$ \\
BW 348-1 & $3.3 \mathrm{ab}$ & $0.0 \mathrm{~b}$ & $2.3 \mathrm{ab}$ & $2.0 \mathrm{ab}$ \\
Local Variety (Control) & $0.0 \mathrm{~b}$ & $0.0 \mathrm{~b}$ & $0.0 \mathrm{~b}$ & $0.0 \mathrm{~b}$ \\
S.E $( \pm)$ & 1.0 & 1.1 & 1.1 & 1.2 \\
CV. $(\%)$ & 56.6 & 70.0 & 66.1 & 50.4 \\
\hline
\end{tabular}

Means within the same column followed by the same letters are not significantly different $(P=0.05)$ from one another using SNK

Table 7. Combined grain yield $(\mathrm{kg} / \mathrm{ha})$ and other parameters in $P$. scrobiculatum infested rice field during 2004 to 2007 seasons at Edozhigi, Nigeria

\begin{tabular}{lllll}
\hline Treatments & $\begin{array}{l}\text { Days to 50\% } \\
\text { Flowering }\end{array}$ & $\begin{array}{l}\text { Plant height at } \\
\text { Harvest } \mathbf{( c m})\end{array}$ & $\begin{array}{l}\text { Panicles per } \\
\text { metre square }\end{array}$ & $\begin{array}{l}\text { Grain Yield } \\
(\mathbf{k g} / \mathbf{h a})\end{array}$ \\
\hline FARO 51 (Cisadane) & $93.1 \mathrm{c}$ & $40.5 \mathrm{c}$ & $269.7 \mathrm{~b}$ & $2084.8 \mathrm{~b}$ \\
FARO 52 (WITA 4) & $100.5 \mathrm{~b}$ & $99.3 \mathrm{~b}$ & $285.3 \mathrm{ab}$ & $2209 / 7 \mathrm{a}$ \\
FARO 37 (ITA 306) & $88.5 \mathrm{~d}$ & $79.0 \mathrm{~d}$ & $271.0 \mathrm{~b}$ & $1996.7 \mathrm{~b}$ \\
TOS 14519 & $108.7 \mathrm{a}$ & $114.4 \mathrm{a}$ & $313.5 \mathrm{a}$ & $2075.2 \mathrm{~b}$ \\
BW 348-1 & $87.7 \mathrm{~d}$ & $94.9 \mathrm{bc}$ & $221.8 \mathrm{c}$ & $1833.6 \mathrm{c}$ \\
Local Variety (Control) & $97.0 \mathrm{bc}$ & $112.5 \mathrm{a}$ & $278.5 \mathrm{ab}$ & $2013.1 \mathrm{~b}$ \\
\hline Mean & 95.9 & 98.4 & 273.3 & 2039.0 \\
S.E. $( \pm)$ & 3.0 & 3.8 & 20.8 & 81.3 \\
C.V. $(\%)$ & 5.2 & 6.6 & 13.1 & 6.9 \\
\hline
\end{tabular}

Mean within the column followed by the same letters are not significantly different $(P=0.05)$ from one another using SNK

\section{DISCUSSIONS}

The presence of $P$. scrobiculatum galls in the one metre band surrounding five of the rice genotypes is important for the result obtained in the study. These $P$. scrobiculatum galls served as sources for parasitoids build up influencing gall midge infestation at 42 DAT and 63 DAT by lowering infestation levels of the genotypes below their normal potentials. For instance, FARO 37 being a highly susceptible variety should have scored higher gall midge infestation than scoring as low as $7.0 \%$ in 2007. This indicated the possibility of the moderating effect of $P$. scrobiculatum galls with their associated parasitoids attraction. Harris et al., 1999 had earlier indicated the possibility of parasitoids movement from galls of $P$. scrobiculatum plants to the galls of rice. Similarly, Nwilene et al., 2008 showed the possibility of using $P$. scrobiculatum as biological control agent of AfRGM. The fact that local variety not surrounded with $P$. scrobiculatum continues to maintain high infestation levels midge points to the moderating effect of $P$. scrobiculatum galls with associated parasitoids. Though TOS 14519 and BW 348-1 are known to have some resistance traits in them, their infestation scores were lower in the study because other studies have reported high score of gall midge infestation on them Gana et al., 2000; Nwilene et al., 2002. The explanation for the trends of infestation at 42 DAT could also be responsible for 63 DAT (Nwilene et al., 2006; 2007).

The deviation from the normal rating status of the rice genotypes involved in this study could also be attributed to moderating effect of $P$. scrobiculatum galls, in reducing gall midge infestation levels. This is why FARO 37 which is a highly susceptible genotype rated moderately susceptible in 2005 and 2007. The local variety which had no $P$. scrobiculatum plants, rated susceptible throughout possibly due to lack of any moderately effect because of the absence of $P$. scrobiculatum.

The fact that parasitism did take place at all is encouraging because this could have substantial importance in gall midge infestation reduction. Nwilene et al., (2000) subjected four rice varieties to parasitism and 
found out that all of them were parasitized. One of the goals which the present study intended to achieve was to generate parasitoids for the rice gall midge attack.

A fact of particular importance is that FARO 37 which is a gall midge susceptible variety gave highest number $P$. Diplosisae and A. procerae at either 42 DAT or 63 DAT. This could have accounted for lower gall midge infestation levels than its known potentials confirming the potential of $P$. scrobiculatum as biological control agent as far as African rice gall midge is concerned.

The significant differences observed in the number of days to $50 \%$ flowering could have been due to varietal differences since each variety has its peculiar number of days to $50 \%$ flowering dependent on the duration of maturity period of the variety which differs from one another. This is in addition to gall midge infestation levels. The different individual traits as it relates to each could be responsible for significant differences observed in plant height, number of panicles per metre square and grain yield. This is because each variety has its inherent potentials as relates to these traits in addition to gall midge infestations levels.

In conclusion, while the search for a truly gall midge resistant variety of rice is on-going incessant outbreaks can be reduced in gall midge endemic areas. The combination of tolerant levels of these varieties used in this study and the potential of $P$. scrobiculatum in building up parasitoids could complements each other in keeping down gall midge infestations levels. These could complement other efforts aimed at reducing or managing gall midge in endemic areas.

\section{REFERENCES}

Alam MS, Kaung Zan, Allur K (1985). Gall midge (GM) Orseolia oryzivora ( $\mathrm{H}$ and $\mathrm{G})$ in Zambia. Int. Rice Res. Newsletter, 10 (2): 15-16.

Bonzi SM (1980). Wild host plants of the rice gall midge, Orseolia oryzivora (Diptera: Cecidomyiicae) in Upper Volta., West African Rice Development Association Newsletter 2: 5-6.

Bouchard D, Ouedraogo A., Boivin G, Amadou K (1992). Mass rearing and life cycle of the African Rice Gall Midge, Orseolia Oryzivora H and $\mathrm{G}$ in Burkina Faso. Tropical Pest Management. 2: 111 - 120

Dakouo D, Nacro S, Sie M (1988). Evolution serisonniere des infestations des la cecidomyie du riz. Orseolia oryzvora H \& G (Diptera: Cecidomyiidae) dans la Sud Ouest du Burkina Faso. Insect Science and its Applications 9: 469-473.

Gana AS, Maji AT, Ukwungwu MN, Imolehin ED, Ogunremi LT (2000). Rice varieties Development for rainfed lowland ecology of Nigeria, Challenges and opportunities. Paper presented at Inst. Regional Rice Research, Bouake, Cote d'ivoire, April 2000.

Harris KM, Williams CT, Okhidievbie O, Las Salle J, Polaszek A (1999). Description of a new species of Orseolia (Diptera: Cecidomyiidae) from Paspalum in West Africa with notes on its parasitoids, ecology and relevance to national biological control of African rice gall midge, O. oryzivora $\mathrm{H}$. and $\mathrm{G}$. Bulletin of Entomological Research 89: 441-448.

Nacro S, Heinrichs EA, Dakouo D (1996). Estimation of rice yield losses due to African rice gall midge. Orseolia oryzivora H \& G. Int. J. Pest Manage. 42:331-334.
Nwilene FE, Jones MP, Okhidievbie O (2000). Influence of rice varieties on parasitism of African rice gall midge. (AfRGM). International Rice Research Newsletter. 22-23.

Nwilene FE, Williams CT, Ukwungwu MN, Dakouo D, Nacro S, Hamadoun A, Kamara S, Okhidievbie O, Abamu FJ, Adamu A (2002). Reactions of Differential Rice Genotypes to African Rice Gall Midge in West Africa. Int. J. Pest Manage.. 48: 195 - 201.

Nwilene FE, Nwanze KF, Olahidievlbie O (2006). African Rice Gall Midge, Biology, Ecology and Control. Field Guide and Technical Manual. African Rice Centre (WARDA) Cotonou, Benin, 24pp.

Nwilene FE, Ajayi O, Agunbiade TA, Youn O, Togola A, Ukwungwu MN, Dakouo D, Kamara, SI, Hamadoun A (2007). Functional Biodiversity for Sustainable Management of African Rice Gall Midge in Lowland Rice - based Systems. In: proceedings of the $16^{\text {th }}$ International Plant Protection Cogress - in Association with BCPC International Congress - Crop Science and Technology, Scottish Exhibition and Conference Centre, Glasgow, Scotland, United Kingdom, 15 - 18 October 2007, $358-359$.

Nwilene FE, Togola A, Tolulope A, Oga EO, Ukwungwu MN, Hamadoun A, Kamara SI, Dakouo D (2008). Parasitoid biodiversity conservation for sustainable management of the African rice gall midge, Orseolia oryzivora (Diptera:Cecidomyiidae) in lowland rice. Biocontrol Science and Technology. 18:10. 1075-1081.

SAS (1991). SAS Institute, SAS/STAT Users Guide Version 6, Fourth Edition, Volume 2, SAS Institute Cary, N.C, 66pp.

Taylor DR, Fomba SN, Fannah SJ, Bernard HM (1995). African rice midge pest in Sierra Leone. International Rice Research Newsletter $9(3): 21$.

Ukwungwu MN, (1986). Resistance of recommended and traditional varieties to gall midge. International Rice Research Newsletter. 11:8.

Ukwungwu MN, Alam MS (1991). Field resistance of rice cultivars to rice gall midge, Orseolia oryzivora in Nigeria. International Rice Commission Newsletter 40:42-43.

Ukwungwu MN, Joshi RC (1992). The distribution of African rice gall midge, Orseolia oryzivora $\mathrm{H} \& \mathrm{G}$. and its parasitoids in Nigeria. Tropical Pest Management. 38:241-244.

Ukwungwu MN, Misari SM, Nwosu KI (1997). African rice gall midge in Nigeria. Paper presented at Ikwo Abakaliki on WARDA/CABI/ARGM Project $28^{\text {th }}$ February, 1997.

Ukwungwu MN, Joshi R (1992). Evaluation of Asian gall midge resistant varieties for African rice gall midge. International Rice Research Newsletter 17(5):12.

Ukwungwu MN, Winslow MD, John VT (1989). Sever outbreak of rice gall midge (GM) in the savanna zone, Nigeria. International Rice Research Newsletter 14(4): 36-37

Umeh EDN, Joshi RC (1993). Aspects of Biology, Ecology and natural biological control of the African rice gall midge, Orselia Oryzivora $\mathrm{H}$. \& G. (Diptera: Cecidomyiidae) in South East Nigeria. J. Applied Entomol. 116:391-398.

Umeh EDN, Joshi RC, Ukwungwu MN (1991). Natural biological control of African rice gall midge in Nigeria. IITA Research Guide 37, International Institute of Tropical Agriculture (IITA) Ibadan, Nigeria.

William CT, Okhidievbie O, Harris KM, Ukwungwu MN (1999). The host range, annual cycle and parasitoids of the African rice gall midge Orseolia oryzivora H. \& G. (Diptera: Cecidomycidae) in Central and South-east Nigeria, Bulletin of Entomological Research 89:589-597.

How to cite this article: Umaru A.B., Dike M.C., Onu I. and Ukwungwu M.N. (2014). Effects of parasitoids on the severity of African rice gall midge Orseolia oryzivora H. \& G. (Diptera: Cecidomyiidea) in Koda millet, Paspalum scrobiculatum $L$ infested rice genotypes at Edozhigi in Central agro-ecological zone of Nigeria. Int. Res. J. Agric. Sci. Soil Sci. 4(6):101-106 